Document downloaded from:

http://hdl.handle.net/10251/128739

This paper must be cited as:

Romero Gil, I.; Paches Giner, MAV.; Martínez-Guijarro, MR. (2019). Selection of an indicator to assess a highly modified saline ecosystem. The Science of The Total Environment. 693. https://doi.org/10.1016/j.scitotenv.2019.133656

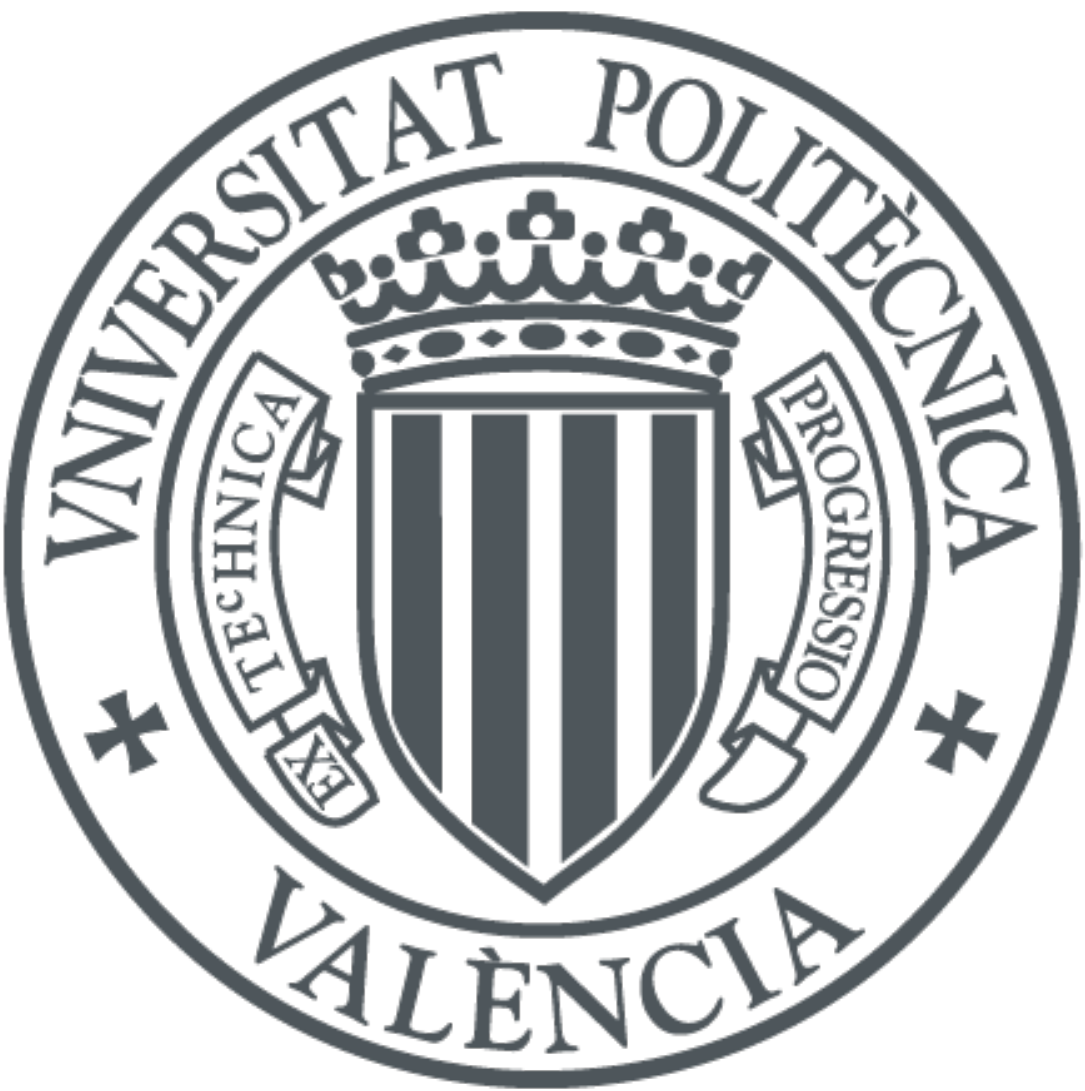

The final publication is available at

https://doi.org/10.1016/j.scitotenv.2019.133656

Copyright Elsevier

Additional Information 


\section{Selection of an indicator to assess a highly modified saline ecosystem}

\section{Inmaculada Romero ${ }^{1, *}$, María Pachés ${ }^{1}$ and Remedios Martínez-Guijarro ${ }^{1}$}

1 Instituto de Ingeniería del Agua y Medio Ambiente (IIAMA). Universitat Politècnica de València. Camino de Vera s/n, 46022 Valencia, Spain; inrogi@dihma.upv.es; mapacgi@upvnet.upv.es; mmarting@hma.upv.es

* Correspondence: inrogi@dihma.upv.es ; Tel.: +00-34-963877616

Abstract: The Water Framework Directive (WFD, 2000/60/EC) determines that all water bodies must achieve a good ecological status. The solar salterns system of Mata-Torrevieja (Spain) has been designated as Heavily Modified Water Bodies (HMWB). This ecosystem is a transitional water body (TW) largely conditioned by socio-economic management plan and the related human activities that take place. Thus, WFD establishes as obligatory the determination of their ecological potential, and not their ecological status. In order to define the ecological potential, it is necessary to determine previously the chemical and biological conditions of the water body. This paper is focused on the analysis of physical-chemical parameters of a saltern system during 2008-2016, in order to establish a starting point for the implementation process of the WFD in this type of ecosystem (TW-HMWB). The behavior of salinity and physical-chemical parameters (temperature, $\mathrm{pH}$, nutrients) have been studied. Salinity was the most relevant parameter studied to define pressures for these water bodies. However, total phosphorus turned out to be a good potential status indicator. It would be one of the most suitable chemical parameters to propose a methodology for the determination of the ecological potential in the salterns.

Keywords: Salterns, Salinity, Phosphorus, Transitional Water, Heavily Modified Water Bodies, Mediterranean Sea

\section{Introduction}

The Water Framework Directive (WFD) (European Union, 2000) establishes a framework for the protection of inland surface waters, transitional waters, coastal waters and 
groundwater. Its main objective is that all water bodies achieve a good ecological status. The WFD requires Member States to distinguish between "natural" and "heavily modified water bodies" (HMWB). The latter are designated as having an acceptably lower ecological status as the result of hydromorphological pressures, which cannot be removed because of the high social or economic cost. Within the scope of the WFD, the solar salterns of the Valencian Community belong to the transitional waters group and have been designated as Transitional Waters (TW) and Heavily Modified Water Bodies (HMWB), according to the Spanish Water Planning Instruction (Ministerio de Medio Ambiente y Medio Rural y Marino, 2008).

Regarding HMWB, WFD establishes as obligatory the determination of their ecological potential, and not their ecological status. This supposes the assumption of certain exceptional conditions and among them a lower ecological status, maintaining at the same level the goals of protection and quality improvement. Because of this, the quality targets for HMWB are "good chemical status" (compliant to natural water bodies) and "good ecological potential", pragmatically defined as the ecological quality expected under the conditions of the implementation of all possible measures (Hering et al., 2010).

For highly modified transitional waters (TW-HMWB), the indicators would be those used in the closest comparable natural surface water category. The indicators, biological, hydromorphological or physical and chemical, valid for these highly modified bodies of water would be those used for the natural transitional water bodies. After selecting the quality elements, Member States (MS) should carry out the process of intercalibration of the different proposed methodologies. The Mediterranean Geographic Intercalibration Group (MedGIG), in its different Intercalibration Phases, has completed the intercalibration in transitional waters (TW) for different biological quality element, but only for natural waters and not for highly modified water bodies (HMWB). The problem is that the intercalibration procedures developed for the types of natural water bodies can not be extrapolated to highly modified water bodies. Moreover, for phytoplankton, there are not enough water bodies in 
the hyperhaline type and only one member state has that typology (Spain). Therefore, Hyperhalines (salinity>40 psu) cannot be intercalibrated, since all WB are HMWB, with a few exceptions in Spain. There are several data set but experts decided not to include the HMWB in the 3rd Intercalibration Phase. Consequently intercalibration exercise is not possible for this typology (Ponis et al., 2018). Moreover, the intercalibration procedures developed for the types of natural water bodies cannot be extrapolated to highly modified water bodies, due to their very different conditions. Therefore, to complete the intercalibration process is not expected in the same way as for natural water bodies. Thus, each Member State is developing its own methodology and criteria for its water bodies.

In fact, in Commission Decision 2018/229 (European Union, 2018), only the transitional waters "Coastal lagoons oligohaline and mesohaline" and "Estuaries" have been intercalibrated for the Biological Quality Element (BQE) phytoplankton and "Coastal lagoons Oligohaline, Mesohaline and Polyhaline" and "Estuaries" for BQE benthic invertebrate fauna. This, together with the wide variety of anthropogenic uses, makes it even more difficult for HMWB to establish common criteria for the indexes, methods and limits among the Member States. Member States should establish their national assessment methods for each national type and, if possible, intercalibrate them. In the case of the national type considered in this document, Spain has not yet established a national assessment method for the different elements of biological quality. Hence the importance of this paper. Thus, for the ecosystem studied in this paper, there are no natural transitional waters with which to compare. In fact, the type "Hyperhaline, salinity> 40 psu" has not been intercalibrated at European level, because in MedGIG, only Spain has this type (Ponis et al., 2018).

Moreover, studies that include quantitative and qualitative environmental data from these highly modified habitats are scarce, however, they are necessary if these areas need to be restored and preserved (Soares et al., 2018). Although there is a large literature on the study of marine and estuarine nutrient and biogeochemical cycles in aquatic systems (Herbert, 1999; Nixon, 1981; Riley and Chester, 1971; Rodríguez, 1982; Romero, 2004; 
Webb, 1981), this kind of studies in saltern systems is proportionally much lower (Soares et al., 2018). Some previous investigations related to physical and chemical parameters and nutrients in saltern systems have been carried out (Barghini et al., 2015; Britton and Johnson, 1987; Costa et al., 2015; Davis and Giordano, 1995; Dolapsakis et al., 2005; Javor, 1983a, 1983b; Javor, 1989, Javor, 2002; Joint et al., 2002; Landry and Jaccard, 1983; López et al., 2010; Oren, 2009; Pedró-Alió et al., 2000). Some research works study the dynamic of environmental conditions, the factors that control water quality and the ecological status (chemical parameters of water and elements of biological quality) of this type of ecosystem (Gecheva et al., 2017).

The salt lakes that are exploited for the production of salt are extreme ecosystems that create particular habitats for a diversity of species (Soares et al., 2018). In this type of ecosystem, effective management and conservation plans must consider their special hydrological and ecological characteristics (Karagianni et al., 2018). In these extreme environments, organisms must adapt to stressful environmental conditions with high variations in abiotic factors (Korovessis and Lekkas, 2009). The trophic chain is intimately related to salinity, and salinity fluctuations should be considered a key factor for typological considerations in quality assessments, restoration and management plans in these ecosystems (Karagianni et al., 2018).

In this type of ecosystem, stressors such as salinity should be considered in future hydrological management plans to preserve water resources, especially in warmer and drier climates. The key factor for a salt lake is the mechanism of salt production and water-freshwater exchange, and the trophic chain in this type of ecosystem is influenced mainly by the gradient of salinity and nutrients (Asencio, 2013; Gecheva et al., 2017; Ladhar et al., 2015; Masmoudi et al., 2015).

In saltern systems, organisms typical of these ecosystems need such specific adaptations that they cannot be found (outside these systems) throughout the saltern salinity range. According to WFD, the ecological state / potential must be defined taking into 
account, in first place, the biological elements, and supporting them, the physical chemical parameters. In the case of these very heterogeneous bodies of water, finding biological parameters common to all WBs of each type is not easy (sometimes it may be impossible). In Valencian Community there are only 3 ecosystems of the same type, hyperhalines, each of them works differently, they have different organisms and different trophic chains, so the physical and chemical parameters can be the most appropriate quality element to define the state of the ecosystem. Indicators are used to assess the state of the environment, provide an early warning signal of changes in the environment or diagnose the cause of an environmental problem (Dale and Beyeler, 2001). Ideally, the indicators used should represent key information about the structure, function and/or composition of the system. Thus, they are relevant for characterize the salterns, physical and chemical parameters (salinity, $\mathrm{pH}$, ammonium, nitrite, nitrate, soluble reactive phosphorus (SRP), total phosphorus (TP) and orthosilicic acid) and their behavior (the variations that these parameters exhibited seasonally, along the salinity gradient or even in different areas within the same saline).

It is complex to establish a criterion for HMWB unless the main environmental processes are well known in this kind of water bodies. Moreover, due to the scarce of deep research carried out in these areas, it is very useful a preliminary research that enable the understanding of the system. Carvalho et al. (2019) point out that one of the main weaknesses of WFD is a "poor linkage between pressures and effects on the ecosystem", and an "insufficient monitoring to identify the cause of degradation". Therefore, it is necessary to improve monitoring to capture the interactions between stressors (Voulvoulis et al., 2017)

Therefore, the main objective of this paper is to study the physical-chemical state of a saltern system (Mata-Torrevieja) in order to establish a starting point for the implementation process of the WFD in this type of ecosystem (TW-HMWB). The salt marshes are considered very important areas since they are essential for the conservation of many 
endemic and rare plant species and migratory water birds (Costa et al., 1987). Moreover, the study area is a Natural Protected Zone as established by the Environmental Agency of the Valencian Community and it is also included in the Ramsar Convention on Wetlands and the Special Protection Area under the European Union Directive on the Conservation of Wild Birds.

\section{Materials and methods}

Mata-Torrevieja (Figure 1) is an unconventional system composed of two large lagoons located in Valencian Community (Spain). The two lagoons make up a single ecosystem. Mata-Torrevieja is used commercially for salt precipitation and extraction, about 600,000 Tm/year (Celdrán and Azorín, 2004), by a private company although the system belongs to the Spanish Estate. However, this salt production can vary annually mainly due to the salinity of the lagoons, for the climatology, precipitation and insolation. This system is the first salt industry in the Spanish state in terms of production volume

This ecosystem has been defined as HMWB, as a result of its hydromorphological pressures. These hydromorphological pressures cannot be eliminated due to their high economic and social cost. The Mata-Torrevieja system is a totally closed "industrial" system that only receives water from two points, depending on the needs for salt production.

Mata saltern is 700 Ha surrounded by scrubs, thymes and Arundo Donax steppe. It is connected to the sea by a channel about 1000 m length that allows seawater entrance to Mata for its previous concentration, before introducing it into Torrevieja. This channel is man-regulated. Mata receives seawater when it is considered necessary to have the proper salinity conditions and be pumped to Torrevieja. It is connected to Torrevieja saltern, by a channel with gates and a pumping station which acts depending on the needs of the salt industry, although water flow usually moves from Mata to Torrevieja.

Torrevieja saltern of $1,400 \mathrm{Ha}$, exhibits a characteristic pink colour due to the presence of halophilic Archaeas and Dunaliella spp, $\beta$-carotene-rich (Amat et al., 1991). Torrevieja also receives water from the washing of a mine of salt rock (Pinoso) with a very high salinity, 
a saturated brine. The Pinoso brines are transported by a conduction for $52 \mathrm{~km}$ away. In this deposit of Pinoso, the extraction of rock salt is carried out, which dissolves to obtain brines. The brines are obtained by dissolving the salt deposit, a jet of water is projected under pressure against the rock salt to dissolve it, obtaining a brine with a very high salt concentration. This entry is also made with the sole objective of maintaining the necessary salinity in Torrevieja in terms of salt production.

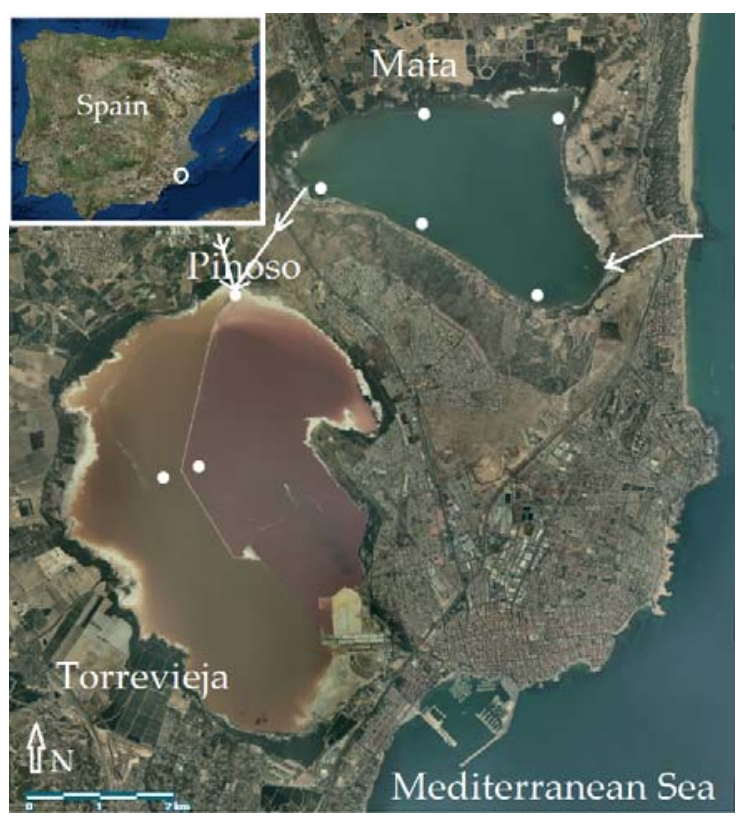

Figure 1. Mata-Torrevieja salterns localization (Valencia-Spain) and sampling sites.

As established by the WFD for physical and chemical parameters in transitional waters, these salterns are sampled every three months. A total number of eighteen sampling campaigns were realized between 2008 and 2016 .

In Mata, water samples were taken at five stations located at different areas of the saltern (Figure 1). In Torrevieja, water samples were taken in two stations in the center of the saltern, each one in a different side of the hillock which divided the lagoon in two parts. These stations reflect properly physical-chemical and biological conditions of the whole saltern. A third sample was taken at the end of the pipe coming from Pinoso (Figure 1). Data 
are also available from the two main sources of water to the ecosystem, the coastal area from where water is pumped to Mata and the water used to wash the Pinoso salt.

In each station, a subsurface water sample is collected in $2 \mathrm{~L}$ polyethylene bottles. Due to its shallowness $(40 \mathrm{~cm})$, the sample might be considered representative of the whole water column. All samples were kept refrigerated until arrival at the laboratory, which never took longer than 12 hours.

In the laboratory, water samples were divided into several equal parts, following the conservation and determination procedures suggested by APHA (2012). The analyzed parameters, except TP, were determined from samples filtered through $0.45 \mu \mathrm{m}$ cellulose acetate membrane filters (Millipore HAWP). Ultrapure water (Milli-Q) was used in analytical methods described.

Temperature was measured in the field using a standard mercury thermometer. The $\mathrm{pH}$ was measured with a WTW $\mathrm{pH}$ meter and conductivity was measured with a Knick Portamess conductimeter, previously calibrated with $\mathrm{KCl}$ and with temperature corrected to $25^{\circ} \mathrm{C}$ (APHA, 2012). Salinity was measured with a Portasal Guildline salinometer previously calibrated with IAPSO Standard seawater (K15=0.99984, salinity 34.9994). Higher salinity samples were previously diluted by weight until achieving salinities closer to seawater.

Nutrients (ammonium, nitrate, nitrite, SRP, orthosilicic acid) were analyzed with an Alliance Instruments Integral Futura air-segmented continuous-flow autoanalyzer. The methodology described by Treguer and Le Corre (1975) was followed, considering Kirkwood et al. (1991) and Parsons et al. (1984) remarks. The equipment optimization was carried out following theories of Coakley (1981). High purity Merck reagents for analysis were used. Higher salinity samples were diluted previously until achieving salinities close to those of seawater.

The TP was determined using the previously digestion method for water developed by Valderrama (1981), where autoclave digestion transforms the total phosphorus into SRP, that is determinated subsequently. 
A statistical treatment (Cluster Analysis, Factor Analysis and multiple regression analysis) was carried out in order to explore patterns of association among physical and chemical variables in the salter system with Statgraphics Centurion XVII. For cluster analysis, Method of Ward, hierarchical agglomerative method, has been used. Previously it has been verified that there is no outlier data and the data have been standardized.

\section{Results}

Mata lagoon works as a great heater pond with salinity concentrations varying between $75.07 \mathrm{~g} / \mathrm{Kg}$ in December 2016 and $183.9 \mathrm{~g} / \mathrm{Kg}$ in October 2010 (Figure 2). In the other hand, Torrevieja acts as a great crystallizer pond. Salinity values ranges between $139.0 \mathrm{~g} / \mathrm{Kg}$ (September 2016) and $276.0 \mathrm{~g} / \mathrm{Kg}$ (April 2008).

The average temperature of Mata-Torrevieja system is $22.5^{\circ} \mathrm{C}$ (Mata $21.83^{\circ} \mathrm{C}$ and Torrevieja $22.58^{\circ} \mathrm{C}$ ), maximum values are about $32^{\circ} \mathrm{C}$ and are registered in summer (July 2009) and minimum is $9.3^{\circ} \mathrm{C}$ in winter (February 2012). Temperature patterns are typical of Mediterranean-type climate with mild winters and hot and dried summers. Pinoso pipe exhibits an average of $22.07^{\circ} \mathrm{C}$ and the temperatures registered are more homogeneous since the maximum is lower and the minimum is higher than the lagoons.

In Mata saltern, the pH values oscillate between 7.7 in February 2009 and 8.6 in July 2009. The pH values in Torrevieja present low variability varying from 7.2 (September 2016) to 7.8 (December 2016).

With regards to ammonium a large spatial and temporal heterogeneous behavior is found in Mata, with values varying from $0.01 \mu \mathrm{M}$ in July 2012 to $526.70 \mu \mathrm{M}$ in April 2008. In Torrevieja saltern the ammonium values are lower and more homogennous temporally. This ranges from $3.10 \mu \mathrm{M}$ in July 2008 to $289.60 \mu \mathrm{M}$ in July 2012 .

Regarding to nitrite and nitrate, in Mata saltern, the highest values are registered in spring, 12.99 $\mu \mathrm{M}$ (May 2010) and $189.40 \mu \mathrm{M}$ (March 2010) respectively. In Torrevieja, very high levels of nitrite and nitrate are detected, $43.84 \mu \mathrm{M}$ in October 2008 and $982.20 \mu \mathrm{M}$ in April 2010, respectively. 
Soluble Reactive Phosphorus (SRP) is almost exhausted in Mata through the studied period (concentrations near to limit of detection $0.01 \mu \mathrm{M}$ ) although significative concentrations are detected in winter in all sampling stations reaching a mean value of 0.10 $\mu \mathrm{M}$ for all sampling campaign. In Torrevieja, the SRP is almost exhausted in most of the sampling campaigns. The maximum value of $3.74 \mu \mathrm{M}$ is found in winter (December 2016).

However, the Total Phosphorus (TP) variation ranges are wide in Mata lagoon (from almost exhausted to $7.1 \mu \mathrm{M}$ in April 2008) and in the Torrevieja lagoon (between almost exhausted to $17.74 \mu \mathrm{M}$ in February 2009). In this saltern, concentrations inside the lagoon are much higher than those from Pinoso brines, from $4.14 \mu \mathrm{M}$ (April 2008) to $0.05 \mu \mathrm{M}$ (July 2012).

The orthosilicic acid values in Mata range between $12.6 \mu \mathrm{M}$ in July 2012 to $75.0 \mu \mathrm{M}$ in July 2008. In Torrevieja saltern, this nutrient vary between $2.9 \mu \mathrm{M}$ in February 2008 and $428.9 \mu \mathrm{M}$ in October 2008.

The Mediterranean Sea is an oligotrophic sea, with low nutrient loads. The seawater that is introduced in La Mata has average values of $37.6 \mathrm{~g} / \mathrm{Kg}$ of salinity, $0.51 \mu \mathrm{M}$ ammonium, $0.05 \mu \mathrm{M}$ nitrite, $1.10 \mu \mathrm{M}$ nitrate, $0.02 \mu \mathrm{M}$ SRP, $0.29 \mu \mathrm{M}$ TP and $1.61 \mu \mathrm{M}$ orthosilicic acid. In fact, Mata lagoon has nutrient concentrations that could be considered acceptable.

Pinoso brines provide high amounts of nutrients to Torrevieja saltern, principally ammonium, nitrate and orthosilicic acid, with maximum values of $545.0 \mu \mathrm{M}$ and $130.2 \mu \mathrm{M}$, respectively. Pinoso salt mine is washed with water from a nearby aquifer. The physicochemical composition of the water used for the washing of rock salt in Pinoso has a salinity of $7.8 \mathrm{~g} / \mathrm{Kg}, \mathrm{pH} 7.67$, ammonium $0.2 \mu \mathrm{M}$, nitrite $<0.01 \mu \mathrm{M}$, nitrate $483.3 \mu \mathrm{M}$, SRP $<0.01 \mu \mathrm{M}$, TP $0.17 \mu \mathrm{M}$ and orthosilic acid $27.8 \mu \mathrm{M}$. So the high values of nitrate that reach Torrevieja are due to the groundwater used to wash the salt. However, it seems that the phosphorus in the lagoon does not come, for the most part, from the brines of the Pinoso salt 
deposit or from the wash water, which has a very low TP content $(0.17 \mu \mathrm{M})$, but possibly from processes internal.
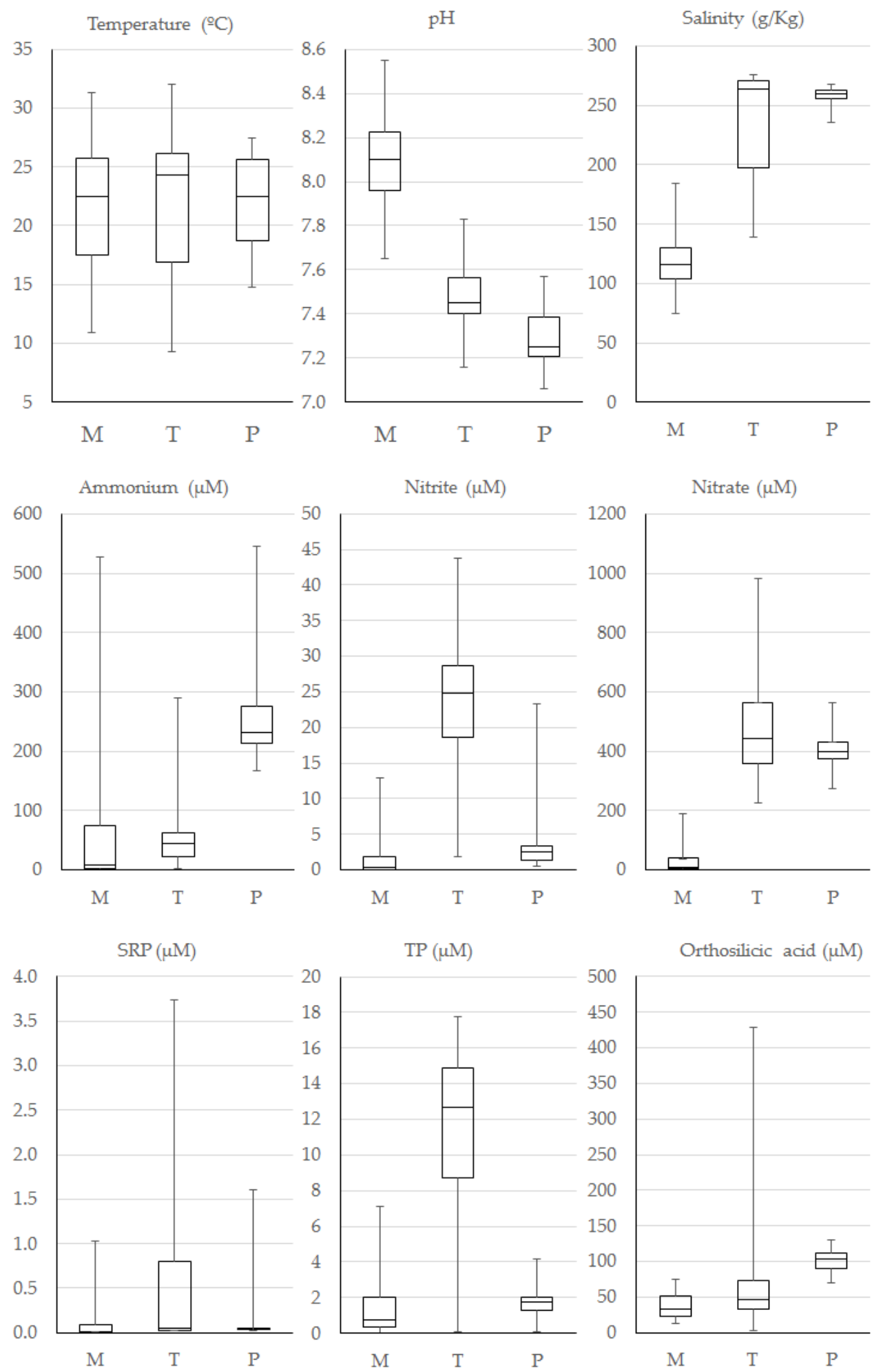
Figure 2. Box-plots Mata, Torrevieja and Pinoso (Minimum value, First quartile, Median, Third quartile and Maximum value)

With the whole data set a cluster analysis was performed. Dendogram (Figure 3) shows that the cases are grouped into two large clusters. One of them corresponds exclusively to Mata. The second one is formed by two small groups that include Torrevieja and Pinoso. It is clear that there are some differences between the two lagoons (Mata-Torrevieja) and that Torrevieja is more similar to Pinoso than to Mata.

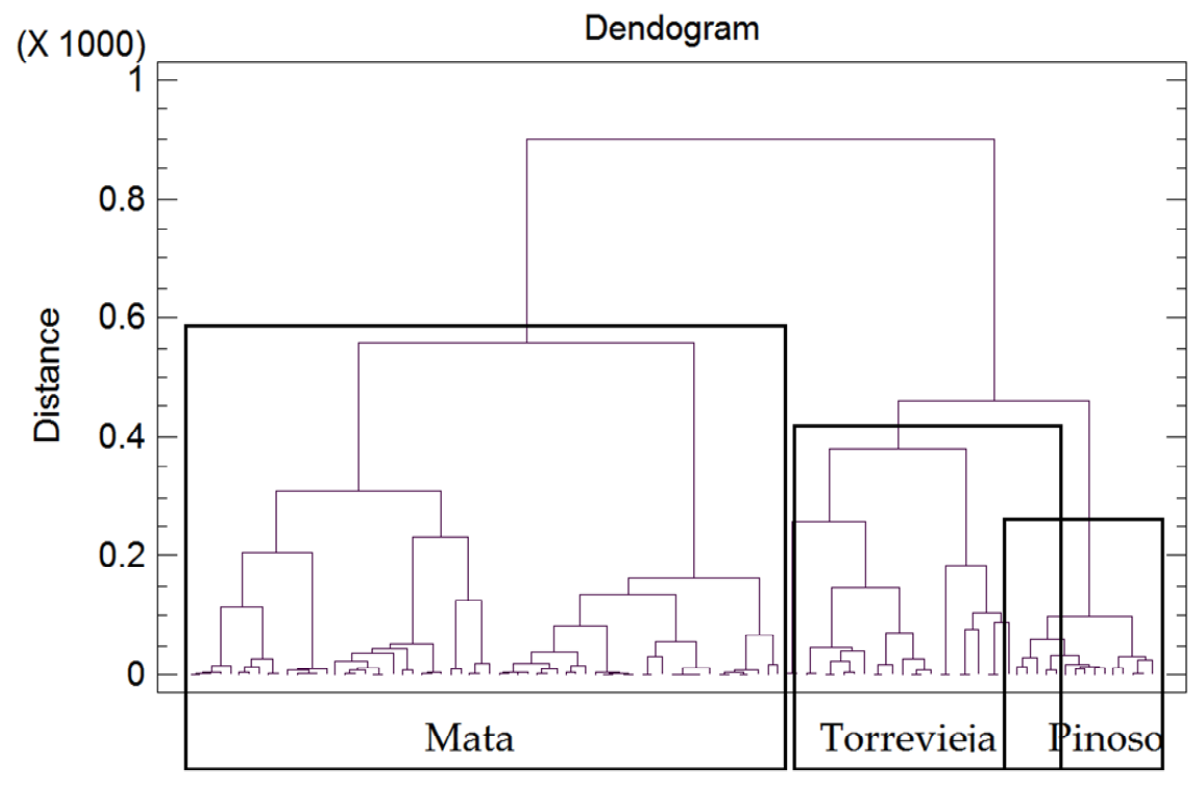

Figure 3. Dendogram.

To verify which variables are those that produce these similarities and dissimilarities, we perform a Factor Analysis with Varimax rotation (FA), with a prior standardization of the data. In this case, 3 factors have been extracted since 3 factors had eigenvalues greater than or equal to 1.0 . Together they explain $75.8036 \%$ of the variability in the original data. The three factors explain the $44.3 \%, 17.7 \%$ and $13.8 \%$ of the total variation, respectively. The Kaiser-Meyer-Olkin's (KMO) measure of sampling adequacy (0.6620) and Bartlett's test of sphericity $(P<0.00001)$ indicated the usefulness of the FA. In Table 1 we can see the variables loading in each factor and in Figure 4 the loadings of sampling sites with respect to the three factors. 
Factor 1 is formed by salinity, nitrite, nitrate and TP and to a lesser extent the SRP in positive, and the $\mathrm{pH}$ in negative. Factor 2 is formed by ammonium and orthosilicic acid in positive and $\mathrm{pH}$ in negative. Factor 3 is formed by the temperature in positive and to a lesser extent SRP in negative.

Table 1. Matrix of Factor loads after Varimax Rotation

\begin{tabular}{cccc}
\hline & Factor 1 & Factor 2 & Factor 3 \\
\hline Temp & 0.00171821 & -0.0837015 & $\mathbf{0 . 9 4 7 3 0 3}$ \\
\hline $\mathrm{pH}$ & $\mathbf{- 0 . 6 8 9 1 4}$ & $\mathbf{- 0 . 6 1 0 7 1 5}$ & 0.192146 \\
\hline Salinity & $\mathbf{0 . 8 2 4 0 5 2}$ & 0.297442 & 0.236125 \\
\hline Ammonium & 0.00747299 & $\mathbf{0 . 8 5 9 5 0 7}$ & -0.305288 \\
\hline Nitrite & $\mathbf{0 . 8 9 3 3 6 7}$ & 0.00463284 & -0.0919667 \\
\hline Nitrate & $\mathbf{0 . 8 2 6 3 4}$ & 0.306318 & -0.0812088 \\
\hline SRP & $\mathbf{0 . 4 5 7 1 7 7}$ & -0.0521559 & $\mathbf{- 0 . 3 7 6 0 1 7}$ \\
\hline TP & $\mathbf{0 . 8 2 6 4 8 8}$ & -0.0993691 & -0.037102 \\
\hline Orthosilicic acid & 0.09014 & $\mathbf{0 . 8 2 4 5 0 7}$ & 0.229319 \\
\hline
\end{tabular}

Figure 4 shows that the samples from Torrevieja and Pinoso are located in the positive part of factor 1 and factor 2 and those of Mata in the negative part of both factors. Thus, the first factor, correlated with salinity, would be linked to the hydrological stress, an assumed stress if the saltern is wanted to be exploited. The second factor, correlated to some nutrients (ammonium and orthosilicic acid), and it would be relate to externs loads for example from Pinoso. In addition, it can be observed that samples from this pipe have the highest coordinates in this axis, while Mata samples, with sea water more oligotrophic, have the lowest ones. On the other hand, for factor 3, no differences are observed between the zones, which are located throughout the axis. Factor 3 is correlated with temperature. The samples with the highest weight in factor 3 are those with the highest temperature (spring 
and summer samples), with the lowest value being those with the lowest temperature (autumn and winter samples).

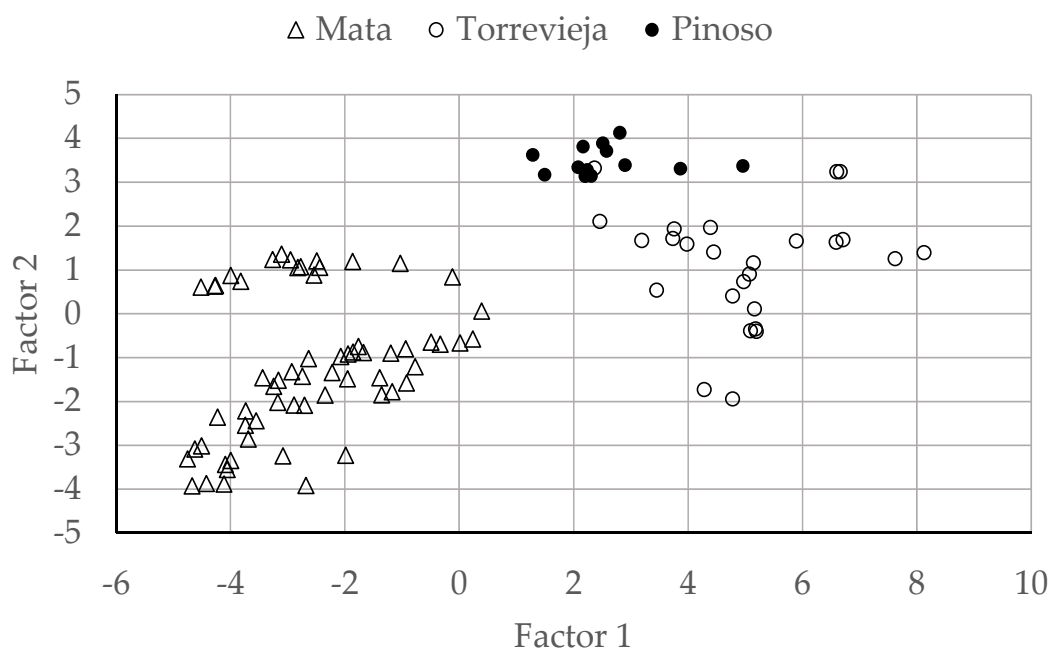

a) Factors 1-2

$\triangle$ Mata $\circ$ Torrevieja $\bullet$ Pinoso

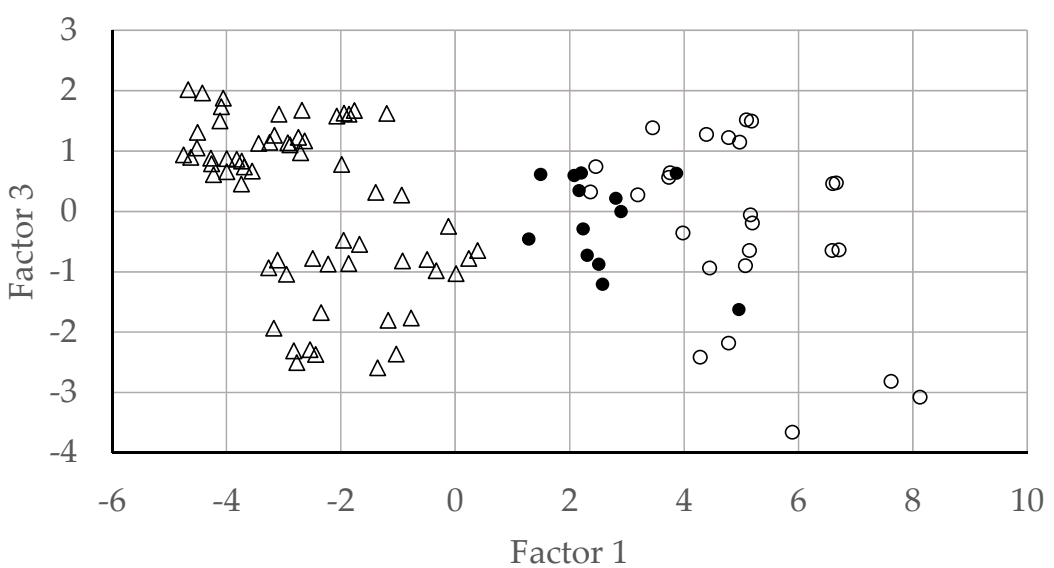

b) Factors 1-3 


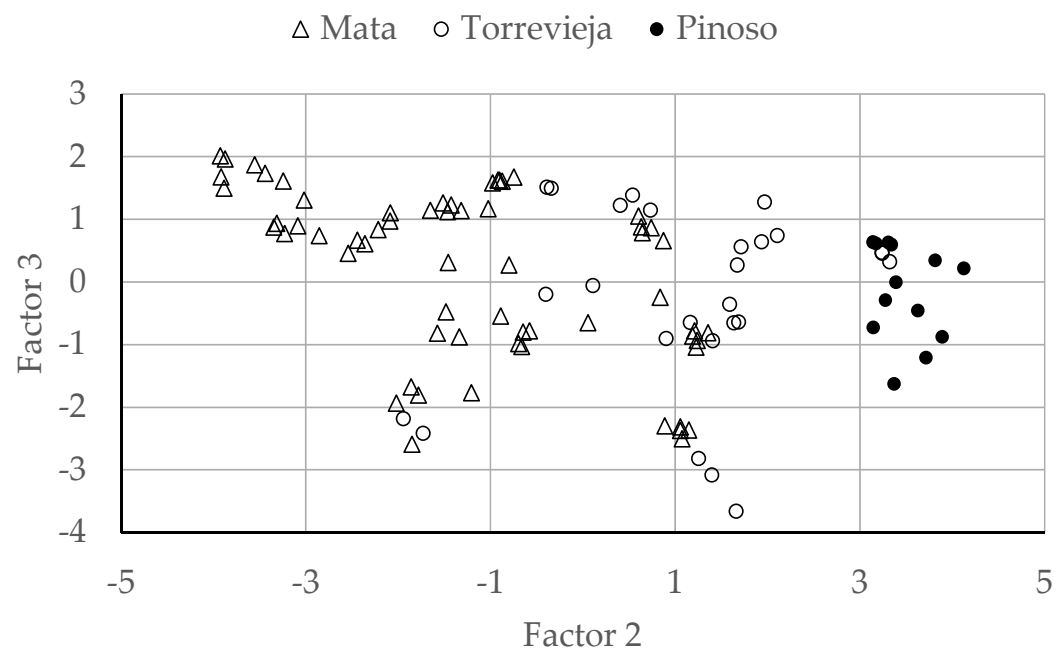

c) Factors 2-3

Figure 4. Loadings of sampling sites a) factors 1-2, b) factors 1-3, c) factors 2-3.

Factor $1(44.3 \%$ of total variation) is correlated positively with salinity, nitrate and nitrite and TP (and to a lesser extent the SRP) and pH in negative (Table 1). This might indicate the external water inputs to the system since these (rainfall, seawater, infiltration, etc.) vary in salinity content and therefore in nutrients composition. Salinity and $\mathrm{pH}$ show an inverse correlation since as salinity increases, the pK1 and pK2 of the Carbonate system decreases while the activity coefficient of $\mathrm{H}+$ increases (Javor, 1989).

Factor 2 (17.7\% of total variation) has positive loadings for ammonium and orthosilicic acid and negative for $\mathrm{pH}$ (although this variable has similar loading for factors 1 and 2). The second component might be link to the biological activity in this high-salinity system. It is well documented the biological activity due to the large number of halophilic and halotolerant eubacteria (Amat et al., 1991) found in these ecosystems beside the Artemia spp., that release large amount of ammonia in their metabolism.

Finally, Factor $3(13.8 \%$ of total variation) correlates with temperature in positive and SRP in negative (although SRP also has positive weight in the factor 1).

Figure 4 can be used to interpret the differences and similarities between the data. It can be seen that almost all the samples from Torrevieja and Pinoso are plotted on the positive side of the first two factors. Salinity, nitrite, nitrate and TP would be the parameters 
that distinguish the chemical conditions with respect to Mata (placed in the negative part of the first two axes). However, this difference is not observed in factor 3 , where all the samples are located homogeneously along the entire axis.

\section{Discussion}

\subsection{Physical and chemical parameters}

In Mata lagoon salinity might be affected by very intense rainfall periods, by seawater inputs due to salt exploitation requirements and by evaporation. Since in this study period there was not any water input from the sea to Mata, the variation of salinity values might only be to rainfall phenomenon. The lower salinity values (minimum $139.0 \mathrm{~g} / \mathrm{Kg}$ ) in Torrevieja lagoon might be due to the high rainfall values registered in autumn, which are the highest for all the study period (AEMET, 2018).

The lowest $\mathrm{pH}$ values founded in Mata lagoon are not due to changes in the ionic composition in a strict sense, but seem to be related to higher water densities that reduce carbon dioxide diffusion and allow its accumulation in water. Taking into account salinity values of Mata, the precipitation of calcium carbonate has probably occurred, since calcium carbonate precipitates when seawater concentrates 2.5-4 times (Lazar et al., 1983). This reduces the ability of the system to regulate the concentration of the carbonic-carbonate system through the calcium carbonate precipitation, and thus buffer the $\mathrm{pH}$ effect on the increase in carbon dioxide inputs. The reduced hydrodynamic of the lagoon together with the high water density $(118.02 \mathrm{~g} / \mathrm{Kg})$ also contribute to carbon dioxide saturation derived from organic matter decomposition. In addition, in most of the cases, gases that lead to a pH decrease seem to come from sediments and not from the water column since ammonium is also associated but not SRP.

These relatively low $\mathrm{pH}$ values in Torrevieja in every sampling campaign are typical of saltern systems with highly concentrated brines. In this saltern, water density is so high that carbon dioxide diffusion is greatly reduced.

\subsection{Ammonium}


The highest values found in Mata seem to come from organic matter mineralization processes that lead high ammonium compounds and from the high biological activity developed in the saltern, since ammonium is released from actively growing zooplankton and by exudation from phytoplankton and bacteria (Berman and Bronk, 2003).

In Torrrevieja, the main entrance of ammonium to the lagoon correspond to Pinoso pipe, since significant ammonium amounts (between 545.4 and $167.2 \mu \mathrm{M}$, average 256.9 $\mu \mathrm{M})$ are detected especially at the station located at the end of the pipe coming from Pinoso. Since the ammonium is the preferential source of nitrogen for the phytoplankton (Estrum-Yousef and Schoor, 2001), much of this is rapidly absorbed while another part might be nitrified, mainly in the nitrite-nitrate form. Moreover, the highest values are found in spring and summer matching with the growth of Artemia sp. which excretions are mainly of $\mathrm{N}$ -ammonium (Ventosa, 2004). Since the density of Artemia sp. in Torrevieja is large (Amat et al., 1991), the amount of ammonium released by these organisms to the water column is considerable.

\subsection{Nitrate and nitrite}

In Mata lagoon there is high temporal variability in nitrite values. In fact, in most campaigns, this nutrient is exhausted (concentrations near to limit of detection $0.01 \mu \mathrm{M}$ ), except in a couple of winter and spring campaigns, where the values are higher $(>4.82 \mu \mathrm{M})$. Nitrate also displays a temporal variability through the studied period although only a couple of campaigns in summer exhibits very low values $(<0.2 \mu \mathrm{M})$. These compounds seem to come from external inputs such as irrigation channels and the nitrification process that take place in the saltern.

For Torrevieja lagoon, these high levels of nitrite and nitrate might come from external inputs, since a thick ravine and watercourse network with intermittent fluvial flow discharge to the saltern (Martí, 2010). For nitrate, there is also a high input from Pinoso (water used to wash the salt provide $483.3 \mu \mathrm{M}$ of nitrate). 
These nitrate and nitrite values also might be due to the halophilic bacteria activity, since they reduce nitrate to nitrite to obtain energy (Amat et al., 1991). There are extremely halophilic denitrifying bacteria in hypersaline environments that may reduce nitrate to nitrite, nitrous oxide and even dinitrogen (Hochstein and Tomlinson, 1985).

In addition, it has been also demonstrated the existence of an inverse process that oxide the ammonium to nitrate and nitrite when low phytoplankton activity prevails mainly in winter (Carpelan, 1957).

\subsection{Phosphorus compounds}

SRP is almost exhausted in both lagoons (concentrations near to limit of detection 0.01 $\mu \mathrm{M})$. This could be due to organic matter mineralization processes coming from the water column and the sediment. The SRP might be the macronutrient which behavior is determinant for the phytoplanktonic productivity in hyperhaline lagoons, and it is rapidly uptake by photosynthetic organisms. Moreover, the solubility products for the different compounds determine the variation in the concentration.

In Torrevieja lagoon, in some cases, the SRP come from Pinoso brines (spring) and in other from the mineralization processes (winter), so there is no a clear behavior pattern for all the sampling campaigns.

As indicated in Serrano et al. (2017), a high concentration of total P in water does not necessarily imply poor quality or poor ecological status in bodies of shallow water that are naturally eutrophic. Their study is based on the chemical equilibrium of $P$ concentrations through the sediment-water interface. They use the total $\mathrm{P} /$ particulate $\mathrm{P}$ ratio (TP/PP) as a tool that distinguishes anthropogenic eutrophication from natural eutrophication. They indicate that when at least $50 \%$ of the samples yield a TP / PP ratio above 2.0 , the excess of SRP could indicate a severe biogenic eutrophication in that particular body of water. In our case, we determined the particulate phosphorus (PP) as the difference between TP and SPR (Serrano et al., 2017). The average TP/PP ratio is 1.1395 , the standard deviation is 0.5045 , the median is 1.017 , the minimum is 1.0015 , the maximum is 4.7222 , the 90 th 
percentile is 1.1305 and the P95 is 2.0 . Of all the samples, only 4 samples have the TP / PP ratio above 2 . Correlation is TP $=1.02491^{*} P P+0.0389238(r 20.9961, p$-value $<0.001)$ for all samples, $\mathrm{TP}=0.984548^{*} \mathrm{PP}+0.0708297(\mathrm{r} 20.9915, \mathrm{p}$-value $<0.001)$ for Mata only, $\mathrm{TP}=$ $1.03396 *$ PP -0.0647388 ( $\mathrm{r} 298.8801, \mathrm{p}$-value <0.001) for Torrevieja only, and TP = $0.979921^{\star} \mathrm{PP}+0.190489(\mathrm{r} 20.83518, \mathrm{p}$-value $<0.001)$ for Pinoso. This indicates therefore that there is no risk of natural eutrophication.

\subsection{Orthosilicic acid}

This nutrient shows in Mata lagoon low coefficient of variation through the studied period indicating that its values are more homogeneous. The highest values may be due to the runoff water inputs from the agriculture fields placed around. In Torrevieja lagoon this nutrient seem to come from Pinoso brines (water used to wash the salt provide $27.8 \mu \mathrm{M}$ ).

\subsection{Characterization of all the salterns}

In salterns ecosystem salinity values reach up $276.0 \mathrm{~g} / \mathrm{Kg}$ yielding extreme environmental conditions in which few well-adapted organisms are found. Generally, the macroscopic diversity is lacking but the microscopic and metabolic diversity are not. Since these ecosystems are mainly microbial (Grant, 2004), it is difficult to find out a bio indicator species for these water bodies, since only those halotolerant species are able to prosper in this extreme condition. Eukaryotes in general are scarce at salinity values found in this ecosystem; however the phototrophic flagellates of the genus Dunaliella reach high density in Torrevieja system (Martí, 2010), suggesting that this genus could be a good indicator.

Dunaliella is found in salinity values $120 \mathrm{~g} / \mathrm{Kg}$ or higher, which means that in Mata-Torrevieja it can be frequent to find it. However, other highly modified salterns nearby this ecosystem in Valencian Community do not exhibit this genus, for that the use of this biological indicator in these TW-HMWB in order to applied WFD requirements might be complex and difficult to determine. 
Among all the elements proposed in the WFD to classify the status (Annex V, WFD), the nutrient conditions, as a physic-chemical elements supporting the biological elements, are the best in this TW-HMWB.

In order to address the establishment of the good potential, it is necessary to analyze the nutrient content and its relation to the pressures. Pressures are defined as "Human activities such as organic pollution, nutrient loading or hydromorphological modification that have the potential to have adverse effects on the water environment" (Ponis et al., 2018). The "Mata-Torrevieja" system has only two external pressures, the Mediterranean Sea and Pinoso pipe. So, in this ecosystem, hydromorphological pressures can be studied through salinity, and therefore salinity involves contributions of nutrients. Thus, salinity might be the chemical parameter that determines the environmental characteristic. Moreover, salinity is a good indicator of water body typology and pressures, although it is not good as a status indicator. In fact, in European Union, salinity is used to define the typology of TW in the intercalibration process (Ponis et al., 2018). Those nutrients revealing good correlation to salinity might be suitable to determine "good status". For that purpose, the determination coefficient $\left(\mathrm{r}^{2}\right)$ was obtained in Statgraphics Centurion XVII. However, only nitrate, nitrite and TP exhibit a significative correlation, $p$-value $<0.05$, with $r^{2} 0.37,0.59$ and 0.36 , respectively. Although whatever of these parameters fit as a status indicator, nitrite and nitrate are rejected because nitrite is the most unstable nitrogen compound, and nitrate show an irregular pattern. Moreover, none of these nitrogen compounds are the limiting nutrients in this type of ecosystems. On the other hand, TP shows a slight linear behavior with salinity and it could be an indicator of adequate potential status. As it has been done for coastal water bodies (Romero et al., 2013), a pressure index must be take into account all land uses in the catchment area and anthropogenic modification in aquatic ecosystems. The objective of quality in this HMWB is adapted to the case of these salt mines, as suggested Hering et al. (2010), and only the elements of biological quality sensitive to pressures are considered. The TP could be used as a pressure and status indicator, since phosphorus is the limiting 
nutrient. In fact, all the phosphorus entering an ecosystem will end up in the short or medium term in particulate form (for example forming part of the biomass) or in dissolved form (for example SRP), so it could be considered as an indicator of the state in the short / medium term.

This is demonstrated by our data. A multiple regression analysis was carried out, with TP being the dependent variable and the rest of nutrients and salinity the independent variables. The equation of the adjusted model is TP $(\mu M)=-0.285542+0.0104001$ * Salinity $(g / K g)+0.00118383 *$ Ammonium $(\mu \mathrm{M})+0.377537 *$ Nitrite $(\mu \mathrm{M})-0.00043828$ * Nitrate $(\mu M)+1.24874$ * SRP $(\mu M)-0.0145022$ * Orthosilicic Acid $(\mu M)$. Since $p$-value $<0.05$, there is a statistically significant relationship between the variables with a confidence level of $95.0 \%$. The R-squared statistic indicates that the model thus adjusted explains $78.8596 \%$ of the variability in TP $(\mu \mathrm{M})$. Relationship between observed and modelled TP is shown in Figure 5.

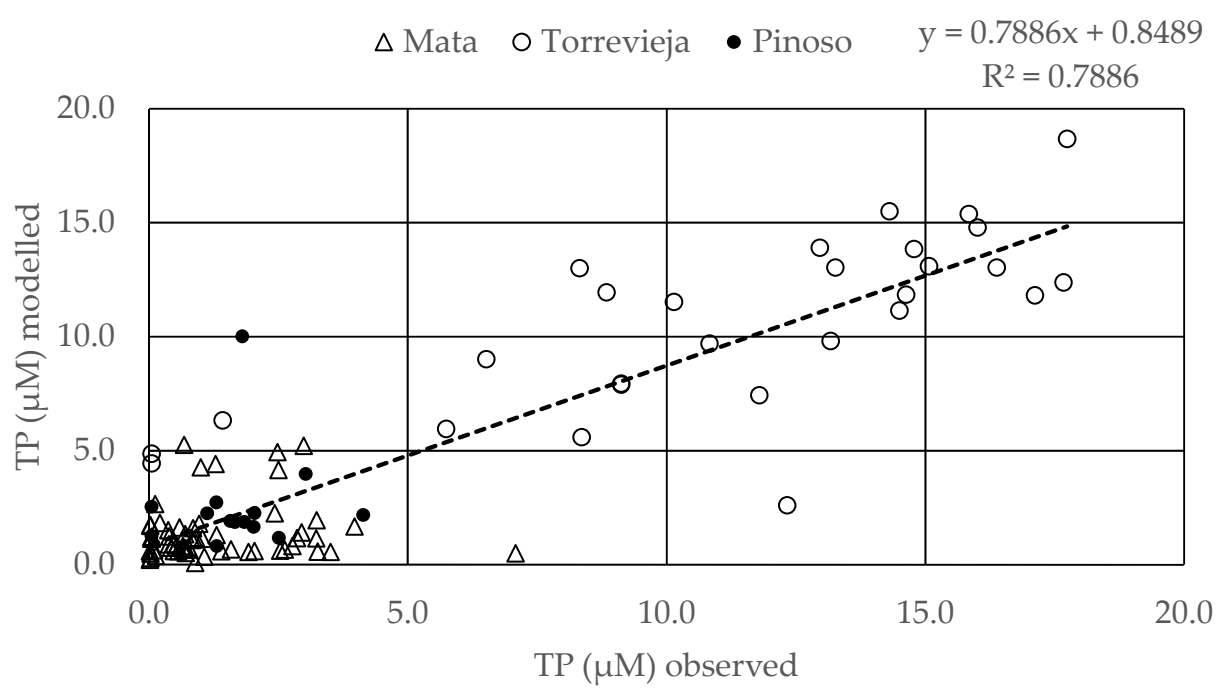

Figure 5. TP modelled and observed.

This good correlation indicates that TP can be considered as a good physical-chemical indicator of the ecosystem, including in itself the variability of the rest of the parameters. Once the indicator to be used has been decided, the next step would be determine the state / potential limits (Phillips et al., 2018; Poikane et al., 2019).

\section{Conclusions}


A preliminary study of the Mata-Torrevieja saltern system has been carried out in order to illustrate the physical-chemical state and to setup the starting point to implement the WFD in these complex ecosystems. The salinity values founded in these salterns are much higher than other heavy modified water bodies found in the Mediterranean area, due to its industrial activity. Torrevieja is a large crystallizer, with salinities close to crystallization point throughout the year, while Mata is a great heater pond.

The Mata-Torrevieja system is a totally closed "industrial" system that only receives water from two points, depending on the needs for salt production. La Mata receives low-nutrient seawater when it is considered necessary to have adequate salinity conditions. Mata introduces water concentrated in salinity to Torrevieja. This lagoon receives, in addition to this water from Mata, water coming from the salt washing of the Pinoso mine. This Pinoso salt is washed with groundwater with a high concentration of nutrients. This brine entry into the system is done with the sole objective of maintaining the required salinity in Torrevieja based on the production of salt.

This fact determines the physical and chemical processes. The ecosystem studied is not a natural aquatic ecosystem, but an artificial one, exploited for the salt extraction. Therefore, the increase in salinity is consequence of the exploitation that must be assumed in a saltern exploitation. Thus, this ecosystem is defined as HMWB. However, salinity can be considered a pressure in this case. The pressure would be the entrance of waters of different salinity that modify the salinity inner values. In addition, these water inputs may be associated to a high nutrient content to the system. Thus, hydromorphological pressures to this ecosystem can be studied through salinity. This salinity pressure brings nutrients, mainly in Torrevieja, where the highest concentrations of nutrients have been found. Thus, the content and nutrient patterns are largely conditioned by the internal processes of the mineralization of organic matter and by the contributions of brines.

The main sources of water in Torrevieja are those from La Mata and those from Pinoso. It is Pinoso that have a very high nutrient content, not only in terms of TP but also in the rest 
of the parameters, mainly nitrates. Therefore, the mitigation measures should be aimed at improving the quality of the waters from Pinoso through the study of measures that reduce the level of nutrients in the waters used in the washing of the rock salt of Pinoso. Since the water used for washing the salt comes from a nearby aquifer, the only viable solution would be to change the water with which the salts are washed and select another source for the salt washing.

Of all the nutrients studied, it is the TP that can be used as an indicator of the state of the ecosystem, because it has a significant correlation with salinity (pressure) and is the limiting nutrient. In addition, all the phosphorus that enters an ecosystem will end up in the short or medium term in the form of particles (for example, forming part of the biomass) or in dissolved form (for example, SRP), so it could be considered as an indicator of the state in the short / medium term.

These considerations are essential when carrying out the WFD Intercalibration process since nutrient cycles, internal processes and human activities are very different in each saline ecosystem. The high salinity reached is compromised by the industrial activity that determines a low planktonic biodiversity. For that, the use of a bioindicator in this ecosystem may not adequately reflect the ecological potential, since only a few specialized species have been able to adapt to this extreme condition. However, total phosphorus (TP) would be one of the most suitable chemical parameters to propose a methodology for the determination of the indicators of potential in these ecosystems. This indicator adjusts appropriately with pressure. The next step will be to determine the state / potential limits.

Funding: This research was funded by Instituto de Ingeniería del Agua y Medio Ambiente (IIAMA) from Universitat Politècnica de València and several regional departments (Conselleria d’Educació, Formació i Ocupació; Conselleria d’Infraestructures, Territori i Medi Ambient and Conselleria d'Agricultura, Pesca, Alimentació i Aigua) de la Generalitat Valenciana. 
Conflicts of Interest: The raw analytical data of these sampling campaigns are property of the Generalitat Valenciana, and its publication is not allowed. Only statistical data can be made public.

\section{References}

- AEMET State Agency of Meteorology, 2018. http://ftpdatos.aemet.es/series_ climatologicas/valores_diarios/estacion/ (accessed 3 April 2018)

- Amat, F., Hontoria, F., Navarro, J.C., Gozalbo, A., Varó, I., 1991. Bioecology of Artemia (Crustacea, Branchiopoda) in La Mata lagoon (Bioecología de Artemia (Crustácea, Branchiopoda) en la laguna de La Mata)), Instituto de Cultura "Juan Gil-Albert”, Alicante, Spain. ISBN 847784996X.

- APHA, 2012. Standard methods for the examination of water and wastewater, 22th ed., American Public Health Association/ American Water Works Association/ Water Environment Federation, Washington DC, USA, ISBN 9780875530130

- Asencio, A.D., 2013. Permanent salt evaporation ponds in a semi-arid Mediterranean region as model systems to study primary production processes under hypersaline conditions. Estuar. Coast. Shelf Sci. 124, 24-33. https://doi.org/10.1016/j.ecss.2013.03.006

- Barghini, P., Aquilantia, A., Silvia, S., Gorrasia, S., Juarez-Jimenez, B., Cordova-Salasa, K., Fenicea, M., 2015. Study on the bacterial diversity of the productive marine salterns 'Saline di Trapani-Paceco', Trapani, Italy. J. Environ. Prot. Ecol. 16 (4), 1389-1396.

- Berman, T., Bronk, D., 2003. Dissolved organic nitrogen: a dynamic participant in aquatic ecosystems. Aquat. Microb. Ecol. 31, 279-305. https://doi.org/10.3354/ame031279

- Britton, R.H., Johnson, A.R., 1987. An ecological account of a Mediterranean salina: the Salin de Giraud, Camargue (S. France). Biol. Conserv. 42, 185-230. https://doi.org/10.1016/0006-3207(87)90133-9 
- Carpelan, L.H., 1957. Hidrobiology of the Alviso Salt ponds. Ecology, 38, 375-390. https://doi.org/10.2307/1929880

- Carvalho, L., Mackay, E.B., Cardoso, A.C., Baattrup-Pedersen, A., Birk, S., Blackstock, K.L., Borics, G., Borja, A., Feld, C.K., Ferreira, M.T., Globevnik, L., Grizzetti, B., Hendry, S., Heringe, D., Kelly, M., Langaas, S., Meissner, K., Panagopoulos, Y., Penning, E., Rouillard, J., Sabater, S., Schmedtje, U., Spears, B.M., Venohr, M., van de Bund, W., Solheimm, A.L., 2019. Protecting and restoring Europe's waters: An analysis of the future development needs of the Water Framework Directive. Sci. Total Environ. 658, 1228-1238. https://doi.org/10.1016/j.scitotenv.2018.12.255

- Celdrán, M.A., Azorín, C., 2004. The industrial operation of the Torrevieja salt lakes (Alicante) (La explotación industrial de las salinas de Torrevieja (Alicante)). Investigaciones Geográficas, 35 , 105-132. https://doi.org/10.14198/INGEO2004.35.01

- Coakley, W.A., 1981. Handbook of automated analysis: Continuous flow techniques, Marcel Dekker: New York, USA, ISBN 9780824713928.

- $\quad$ Costa, D.F.S., Barbosa, J.E.L., Soares, A.M.V.M., Lillebo, A.I., Rocha, R.M.R., 2015. Spatial modeling of limnological parameters in a solar saltwork of northeastern Brazil. Acta Limnologica Brasiliensia, $27 \quad$ (1), 105-117. https://doi.org/10.1590/S2179-975X2114

- Costa, M., Perez-Badia, R.M., Soriano, P., 1987. La vegetación como elemento de diagnóstico en la conservación del litoral. Colloques Phytosociologiques 15, 281-298.

- Dale, V.H., Beyeler, S.C., 2001. Challenges in the development and use of $\begin{array}{lllll}\text { ecological indicators. } & \text { Ecol. } & \text { Indic. } & 1 & (1),\end{array}$ https://doi.org/10.1016/S1470-160X(01)00003-6 
- Davis, J.S., Giordano, M., 1995. Biological and physical events involved in the origin, effects, and control of organic matter in solar saltworks. International Journal of Salt Lake Research. 4, 335-347. https://doi.org/10.1007/BF01999117

- Dolapsakis, N.P., Tafas, T., Abatzopoulos, T.J., Ziller, S., Economou-Amilli, A., 2005. Abundance and growth of microalgae at Megalon Embolon solar saltworks in northern Greece: an aquaculture prospect. J. Appl. Phycol. 17, 39- 49. https://doi.org/10.1007/s10811-005-5553-0

- Estrum-Yousef, S.R., Schoor, A., 2001. Seasonal variation of nitrogen transformations in the pelagial of selected nearshore waters of the Baltic Sea with emphasis on the particulate pool. Hydrobiologia, 450, 19-30. https://doi.org/10.1023/A:1017521400253

- European Union, 2000. Directive 2000/60/EC of the European Parliament and of the Council of 23th October 2000, establishing a framework for the Community action in the field of water policy. WFD 2000/60/EC. http://data.europa.eu/eli/dir/2000/60/oj

- European Union, 2018. Commission Decision (EU) 2018/229 of 12 February 2018 establishing, pursuant to Directive 2000/60/EC of the European Parliament and of the Council, the values of the Member State monitoring system classifications as a result of the intercalibration exercise and repealing Commission Decision 2013/480/EU. http://data.europa.eu/eli/dec/2018/229/oj

- Gecheva, G.M., Varadinova, E.D., Belkinova, D.S., Mihov, S.D., Gyuzelev, G.A., Hristeva, Y.G., 2017. Ecological Status Assessment of a Hypersaline Lake: a Case Study of Atanasovsko Lake, Bulgaria. Acta Zool. Bulg., Supplement 8, 145-151.

- Grant, W.D., 2004. Life at low water activity. Philosop Philos. Trans. R. Soc. B-Biol. Sci. 359, 1249-1267. https://doi.org/10.1098/rstb.2004.1502

- Herbert, R.A., 1999. Nitrogen cycling in coastal marine ecosystems. Fems Microbiol. Rev. 23, 563-590. https://doi.org/10.1111/j.1574-6976.1999.tb00414.x 
- Hering, D., Borja, A., Carstensen, J., Carvalho, L., Elliott, M., Feld, C.K., Hesikanen, A., Johnson, R.K., Moe, J., Pont, D., Solheim A.L., van de Bund, W., 2010. The European Water Framework Directive at the age of 10: A critical review of the achievements with recommendations for the future. Sci. Total Environ. 408, 4007-4019. https://doi.org/10.1016/j.scitotenv.2010.05.031

- Hochstein, L., Tomlinson, G., 1985. Denitrification by extremely halophilic bacteria. $\begin{array}{llll}\text { FEMS } & \text { Microbiol. } & \text { Lett. } & 27,\end{array}$ https://doi.org/10.1111/j.1574-6968.1985.tb00691.x

- Javor, B.J., 1983a. Nutrients and ecology of the Western Salt and Exportadora de Sal saltern brines, in: Schreiber, B.C., Harner, H.L. (Eds.), 6th Symposium on Salt. The Salt Institute, Toronto, pp. 195-205.

- Javor, B.J., 1983b. Planktonic standing crop and nutrients in a saltern ecosystem. Limnol. Oceanogr. 28, 153-159. https://doi.org/10.4319/lo.1983.28.1.0153

- Javor, B.J., 1989. Hypersaline environments. Springer-Verlag: Berling Heidelberg. ISBN 9783642743726.

- Javor, B.J., 2002. Industrial microbiology of solar salt production. J. Ind. Microbiol. Biotechnol. 28, 42-47. https://doi.org/10.1038/sj/jim/7000173

- Joint, I., Henriksen, P., Garde, K., Riemann, B., 2002. Primary production, nutrient assimilation and microzooplancton grazing along a hypersaline gradient. FEMS Microbiol. Ecol. 39, 245-257. https://doi.org/10.1111/j.1574-6941.2002.tb00927.x

- Karagianni, A., Stamou, G., Katsiapi, M., Polykarpou, P., Dörflinger, G., Michaloudi, E., 2018. Zooplankton communities in Mediterranean temporary lakes: the case of saline lakes in Cyprus. Ann. Limnol. - Int. J. Lim. 54, 14. https://doi.org/10.1051/limn/2018007

- Kirkwood, D., Aminot, A., Pertilla, M., 1991. Report on the results of the ices fourth intercomparison exercise for nutrients in sea water. ICES Coop Res Rep, 174. 
- Korovessis, N.A., Lekkas, T.D., 2009. Solar Saltworks' Wetland Function. Global NEST Journal, Vol 11, No 1, pp 49-57

- Ladhar, C., Tastard, E., Casse, N., Denis, F., Ayadi, H., 2015. Strong and stable environmental structuring of the zooplankton communities in interconnected salt ponds. Hydrobiologia, 743, 1-13. https://doi.org/ 10.1007/s10750-014-1998-y

- Landry, J.C., Jaccard, J., 1983. Chimie des eaux libres dans le marais salant de Salin-de-Giraud (Sud de la France). Géologie Mediterranéenne 9, 329-348. https://doi.org/10.3406/geolm.1982.1214

- Lazar, B., Starinsky, A., Katz, A., Sass, E., 1983. The carbonate system in hypersaline solutions: alkalinity and $\mathrm{CaCO} 3$ solubility of evaporated seawater. Limnol. Oceanogr. 28, 978-986. https://doi.org/10.4319/lo.1983.28.5.0978

- López, E., Aguilera, P.A., Schmitz, M.F., Castro, H., Pineda, F.D., 2010. Selection of ecological indicators for the conservation, management and monitoring of Mediterranean coastal salinas. Environ. Monit. Assess. 166, 241-256. https://doi.org/10.1007/s10661-009-0998-2

- Martí, C.M., 2010. Caracterización ecológica y establecimiento de los criterios para determinar el potencial ecológico en las salinas de la Comunidad Valenciana. PhD Thesis, Universitat Politècnica de València, Valencia, Spain.

- Masmoudi, S., Tastard, E., Guermazi, W., Caruso, A., Morant-Manceau, A., Ayadi, H., 2015. Salinity gradient and nutrients as major structuring factors of the phytoplankton communities in salt marshes. Aquat. Ecol. 49, 1-19. https://doi.org/10.1007/s10452-014-9500-5

- Ministerio de Medio Ambiente y Medio Rural y Marino, 2008. Orden ARM/2656/2008, de 10 de septiembre, por la que se aprueba la instrucción de planificación hidrológica, Spain. 
- Nixon, S.W., 1981. Remineralization and nutrient cycling in coastal marine ecosystems, in: Neilson, B.J., Cronin L.E. (Eds.), Estuaries and nutrients. Humana Press Inc., New Jersey, pp. 111-138, ISBN 9781461258285.

- Oren, A., 2009. Saltern evaporation ponds as model systems for the study of primary production processes under hypersaline conditions. Aquat. Microb. Ecol. 56, 193-204. https://doi.org/10.3354/ame01297

- Parsons, T.R., Maita, Y., Lalli, C.M., 1984. A manual of chemical and biological methods for seawater analysis. Pergamon Press: New York, USA, ISBN 9780080302874.

- Pedrós-Alió, C., Calderón-Paz, J.I., MacLean, M.H., Medina, G., Marrasé, C., Gasol J.M., Guixa-Boixereu, N., 2000. The microbial food web along salinity gradients. $\begin{array}{llll}\text { FEMS } & \text { Microbiol. } & \text { Ecol. } & 32,\end{array}$ https://doi.org/10.1111/j.1574-6941.2000.tb00708.x

- Phillips, G., Kelly, M., Teixeira, H., Salas, F., Free, G., Leujak, W., Pitt, JA., Lycge Solheim, A., Varbiro, G., Poikane, S., 2018. Best practice for establishing nutrient concentrations to support good ecological status. EUR 29329 EN, Publications Office of the European Union, Luxembourg, 2018, ISBN 978-92-79-92906-9, https://doi.org/10.2760/84425, JRC112667

- Poikane, S., Phillips, G., Birk, S., Free, G., Kellye, M.G., Willby, N.J., 2019. Deriving nutrient criteria to support 'good' ecological status in European lakes: An empirically based approach to linking ecology and management. Sci. Total Environ. 650, 2074-2084

- Ponis, E., Giovanardi, F., Facca, C., Buchet, R., Derolez, V., Bernardi Aubry, F., Pagou, K., Garcia, E., Ninevic, Z., Costas, N., Pardo, I., Salas Herrero, F., 2018. Transitional waters Mediterranean Geographic Intercalibration Group. Phytoplankton ecological assessment methods, EUR 29607 EN, Publications Office 
of the European Union, Luxembourg, JRC114726, ISBN 978-92-79-98683-3, https://doi.org/10.2760/239940

- Riley, J.P., Chester, R., 1971. Introduction to marine chemistry. Academic Press, London. ISBN 9780125887502.

- Rodríguez, J., 1982. Mediterranean Sea oceanography (Oceanografía del Mar Mediterráneo). Pirámide, Madrid, Spain. ISBN 9788436801903.

- Romero, I., 2004. Comportamiento de nutrientes en la pluma del río Ebro. PhD Thesis. Universitat Politècnica de València, Valencia, Spain.

- Romero, I., Pachés, M., Martínez-Guijarro, R., Ferrer, J., 2013. Glophymed: An index to establish the ecological status for the Water Framework Directive based on phytoplankton in coastal waters. Mar. Pollut. Bull. 75, 218-223. https://doi.org/10.1016/j.marpolbul.2013.07.028

- Serrano, L., Reina, M., Quintana, X. D., Romo, S., Olmo, C., Soria, J.M., Blanco, S., Fernández-Aláez, C., Fernández-Aláez, M., Caria, M.C., Bagella, S., Kalettka, T., Pätzig, M., 2017. A new tool for the assessment of severe anthropogenic eutrophication in small shallow water bodies. Ecol. Indic. 76, 324-334.

- Soares, R.H.R.M., Assunção, C.A., Fernandes, F. O., Marinho-Soriano, E., 2018. Identification and analysis of ecosystem services associated with biodiversity of saltworks. Ocean Coastal Manage. $163 \quad$ (1), 278-284. https://doi.org/10.1016/j.ocecoaman.2018.07.007

- Treguer, P., Le Corre, P., 1975. Manuel d'analyse des sels nutritifs dans l'eau de mer. Univ Bret Occ: Brest.

- Valderrama, J. C., 1981. The simultaneous analysis of total nitrogen and total phosphorus in natural waters. Mar. Chem. 10 (2), 109-122. https://doi.org/10.1016/0304-4203(81)90027-X

- Ventosa, A., 2004. Halophilic microorganisms. Springer-Verlag Berlin Heidelberg, New York, USA, ISBN 978-3-662-07656-9 
- Voulvoulis, N., Arpon, K.D., Giakoumis, T., 2017. The EU Water Framework Directive: From great expectations to problems with implementation. Sci. Total Environ. 575, 358-366. http://dx.doi.org/10.1016/j.scitotenv.2016.09.228

- Webb, K.L., 1981. Conceptual models and processes of nutrient cycling in estuaries, in: Neilson, B.J. and Cronin, L.E. (Eds.), Estuaries and nutrients. Humana Press Inc., New Jersey, pp. 25-46, ISBN 9781461258285. 